\title{
Malay and Non-Malay Working Adults: Multigroup-Analysis on the Differences of Influence Between the Frequent Watched Programs on Portal Tv and Satisfaction on Gratification Needs
}

Norliana Hashim, Muhammad Nur Fitri Razak \& Sun Huiwen

To Link this Article: http://dx.doi.org/10.6007/IJARBSS/v11-i8/10607

DOI:10.6007/IJARBSS/v11-i8/10607

Received: 08 June 2021, Revised: 12 July 2021, Accepted: 30 July 2021

Published Online: 23 August 2021

In-Text Citation: (Hashim et al., 2021)

To Cite this Article: Hashim, N., Razak, M. N. F., \& Huiwen, S. (2021). Malay and Non-Malay Working Adults: Multigroup-Analysis on the Differences of Influence Between the Frequent Watched Programs on Portal Tv and Satisfaction on Gratification Needs. International Journal of Academic Research in Business and Social Sciences, 11(8), 1852-1866.

Copyright: (c) 2021 The Author(s)

Published by Human Resource Management Academic Research Society (www.hrmars.com) This article is published under the Creative Commons Attribution (CC BY 4.0) license. Anyone may reproduce, distribute, translate and create derivative works of this article (for both commercial and non-commercial purposes), subject to full attribution to the original publication and authors. The full terms of this license may be seen

at: http://creativecommons.org/licences/by/4.0/legalcode

Vol. 11, No. 8, 2021, Pg. 1852 - 1866 


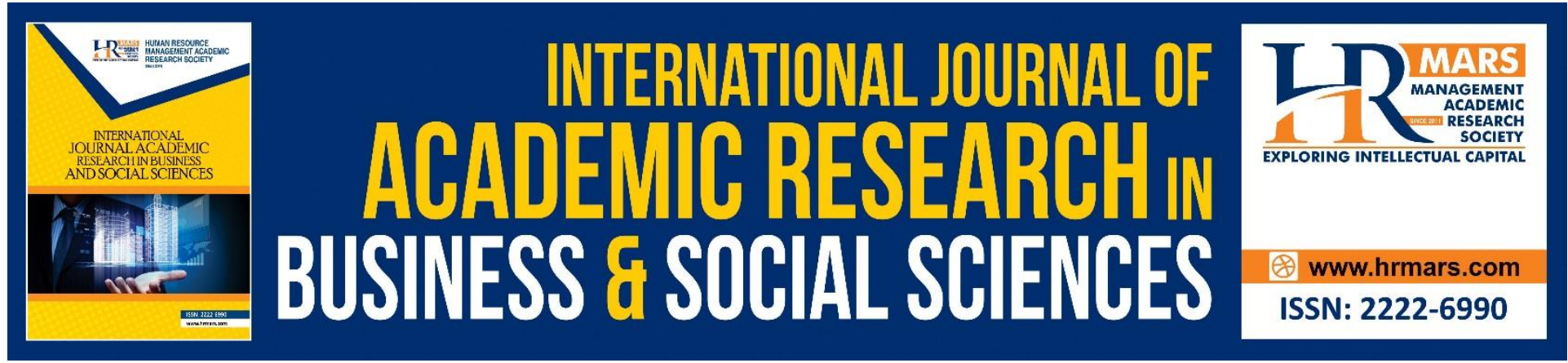

\title{
Malay and Non-Malay Working Adults: Multigroup-Analysis on the Differences of Influence Between the Frequent Watched Programs on Portal Tv and Satisfaction on Gratification Needs
}

\author{
Norliana Hashim, Muhammad Nur Fitri Razak \& Sun Huiwen \\ Universiti Putra Malaysia
}

\begin{abstract}
Changes in the Malaysian mass media landscape are on the rise and this has given the audience more choice to watch their favorite channels. There is a remarkable shortage of research on audiences that are now active and selective where the power to choose the media is in the hands of the audience itself. However the current situation sees only certain channels occupying the hearts of viewers; only certain channels have the highest ratings, but they show significant differences. To address this gap, this study was conducted in which we tested the Influence of viewing patterns, viewer decision-making on the frequency of TV channel selection in broadcasting organizations of traditional television and portal television in Malaysia. In this survey, 500 participants of various backgrounds from the area around Bandar Baru Bangi were involved. The result is mainly to illustrates the significance of this study enhances the impact of the boom of the media industry. Limitations and practical implications are provided.
\end{abstract}

Keywords: Multigroup Analysis, Portal TV, Students, Uses and Gratifications Theory, Working Adults.

\section{Introduction}

This decade the world is colored by various television channels. Name everything, from songs, dramas, movies, news, even sports and games to today's madness through a realitybased entertainment show that grows mushrooms after rain. The madness of entertaining through television shows as if they were 'staple food' is not only a place to relieve stress, but also a desire that can never be contained. Particularly when the media step into the digital 
age, each person's media choices are further shaped by his or her social networks (James, 2015).

Although the research of Television viewing patterns has already been conducted since 1982 by Rubin, researchers pay attention to the comparison while the development of media technology (Mazni, 2007; Andrew et al, 2014; Ghazali \& Ezhar, 2018; Nizam, 2018) keeps evaluating between traditional TV and portal TV (Ali et al., 2011) in Malaysia. The practical importance of studying the audience or viewers is mainly because of the commercial running pattern of traditional TV and portal TV, gathering a stable income from these stakeholdersviewers or audiences. Due to the behavior of viewing determine the rating for every channel, the more audience views the channel, the more income will be produced, no matter from advertisement investing or the voluntary purchase for their favorite channel. In the academic perspective for the viewer-oriented survey, the decision made by the viewer determines one media platform survive or die, such as the doom of the newspaper and the boom of the portable viewing device.

Evidently, the media need an audience before they can achieve a purpose. Hence, traditional TV audience ratings fail to stand for the total number of TV viewers. The innovation of digital technology provides more opportunities for the development of the entertainment media industry. This industry boom has also brought fierce competition between various programming sources and delivery channels. And they have to compete with one another in the marketplace of attention to targeting the Audience (James, 2015). Thus, there are two types of viewing patterns were tested in previous research; television viewing behaviors (viewing levels and program preferences) and television attitudes (affinity and realism) (Rubin, 2009). Therefore, many academic researchers have acknowledged that the relationship between the viewing pattern and the audience's motivation (Rubin, 1982) the policy television in Malaysia (Karthigesu, 1990) Malaysian Television channel (John, 1976; Noor, 1997) and program loyalty (Peter, 1993; Ahmad et al., 2019;). The much stronger evidence displayed that the audience flow model of Television viewing choice was developed by Roland and Mark in 1984. Although previously explored the audience and TV, while little merely focus on the behavior of the viewer viewing TV channel itself that specific choice and specific pattern in the context of the Malaysian media organization.

To further our understanding, we explored which channels are the audience's choice and why are some channels so far superior to their audience ratings. The research questions driving this research are as follows:

i. Is the any significant differences between Malay and Non-Malay on preferred programs on portal TV in satisfying their needs on gratification?

ii. Between Malay and Non-Malay, which population group is having a significant influence on preferred programs on portal TV in satisfying their needs on gratification?

The rest of the article is structured as follows: 1) discussion on literature review 2) research methodology to investigate these questions, we set the angle from cognitive needs, emotional needs, personal needs, social needs, and the stress-releasing need, with quantitative measures of the demography, viewing pattern and viewing choice. 3) conclusion for our research that contribute to the aspect of academic and practical meaning. 


\section{Literature Review \\ Media Consumption Patterns}

Broadcasters are facing issues that audience's shift in the viewing patterns from various media choices, their attention on social media generated content differs from before, and the social media users of the portal creating broadcasting content, and taking over the role of mainstream broadcasting. For example, the numerous broadcast viewers now could enjoy the free programs from FTA broadcasting and free portal TV. While, the digitalized program and superior quality will be a tall order to expect them to pay for a set top box, when the public were used to receiving broadcast content free (Ramachandran \& Mohd, 2015).

Notably, in A Dictionary of Media and Communication published by Oxford University Press in 2011, the breakdown is often based on age, gender, social class, and race. Depending on the average number of views, it may also be different from the viewer category: light viewers (viewing less than 2 hours per day), medium viewers (viewing 2-4 hours), or heavy viewers. Watching is often classified by program type (see also television genres), channel, or daypart (e.g. peak time).

This definition is in line with previous media research which displays that viewing pattern (Manouche \& Martin,1996; Richard et al., 1996; Aviva \& August, 1997; David, 2003; Karren et al., 2003; Zhanna et al., 2010; Beverly et al.,2012; Patric \& Andrew,2014; Mohammad, 2018) is a significant factor which exploring the relationship between television and audience. From tracing the tabulations of rating data in various location the USA, Britain, and elsewhere (Patric \& Andrew,2014), or even the rural and urban area (Tao, 2009), TV viewing time with gender's choice (Takemi et al., 2008), online streaming of web-enabled smart televisions in various age (Alec \& Kim, 2019), adolescents' TV viewing patterns (Leire et al.,2017; Laura \& Bradley,2000) and children's' viewing behavior (John \& Thomas, 1975; Dorothy \& Jerome, 1976; Rubin, 2009) sensation seeking (Richard et al., 1996; Zhanna et al., 2010; Marvin \& Anton, 2015), channel loyalty (Webster \& Wakshlag, 1983; Tiedge \& Ksobiech, 1986; Ahmad et al., 2019) the influence of family income to children's' viewing pattern (Nicola et al., 2011). Therefore, many academic researchers have acknowledged in the context of program loyalty (Peter, 1993; Ahmad et al., 2019). This study will add a new novelty to this in its aim to seek significant differences between Malay and Non-Malay.

Currently, most of the money is spent on content and special features that are broadcast to attract as many viewers as possible (Anderson, 2011). For example, in the Malaysia KRU production film is modernized in terms of special effects, costumes, and animations in the Ribbit story. In this study, we assume that portal TV challenges traditional TV and paid channels in trend now. While, as the latest research results show, though the attractiveness of the media contents, the Jordanian viewers are not completely satisfied with a particular satellite TV channel due to the religious factor. How it goes to Malaysia that has the same Islamic religious social background.

According to the existing approaches to the measurement of the relevant constructs, the much stronger evident displayed that the audience flow model of television viewing choice developed by Roland and Mark in 1984, the model breaks down the population by age, education level and gender. Assuming that the program can be divided into one of nine program types; serious drama, game show, talk, variety, movie, news, sports and comedy (Rolan \& Mark, 1984). Although the previous researchers have already explored the audience 
and TV, while little merely focus on the behavior of viewer viewing TV channel itself that specific choice and specific pattern in the context of Malaysian media organization now.

Theoretically, based on the perspective of use and gratification, A widely adopted theoretical framework for studying media use behavior and effects, assuming that media use behavior is driven by certain internal needs and specific satisfaction motives (Carolyn, 1993). Previously, studies indicate that lifestyle can predict the media selection and use (e.g., Becker \& Connor, 1981; Author, 1998). Research into traditional viewing patterns related to the time of day has been argued to have been eroded by audience fragmentation, media convergence, and the online availability of TV on demand (Patric \& Andrew, 2014), what we know and develop about television and audience or viewers. While, viewing habits may also be conceptualized in time, such as how to use TV viewing to pass the day (Kubey \& Csikzentmihalyi, 1990). This habit has often been manipulated as one of several possible media its use and impacting the seek gratification needs which usually commensurate with factors such as killing time, seeking information, and other explicit needs. Thus Viewers' goals and needs directly contribute to the conceptualization of the Habit Process (Aviva \& August, 1997).

According to the "habitual viewing pattern" model (Aviva \& August, 1997) which developed in order to address the conceptualize viewing habit, and as the importance of instrumental strategy for decreasing cognitive complexity, conceivably, in the choice-laden new media air, habitually driven viewing behavior are more common than early viewing environments, especially with more channel offerings (Aviva \& August, 1997).

Consumption patterns of viewers also was influenced by demographic factors and social institution (i.e. ethnicity) is influenced by mass media and then continued by socialisation process in the form of social learning (modelling, reinforcement, and social interaction), resulted in the outcomes of socialisation process (McLeod \& O'Keefe, 1972; Abd Halim \& Rosidi, 2012). Thus, this contributes to the unique profiles of the preferences of individual identity that might exist for specific patterns or styles of media use (Kurek et al., 2017).

\section{Viewer Decision-Making Equals Customer Decision-Making}

Due to the digital media offer people countless choices (James, 2015). Even if viewers or audiences do not have to pay for content, their existence can justify funding and can constitute an "audience product" sold by television providers to advertisers (Napoli, 2001) which been doubted as the high quality channel such as Astro, Netflix \& TM Streamyx. The TV viewer or audience has already been regarded as the customer in the TV channel research between the TV product (program) and contomer (viewer or audience) satisfaction (Ahmad, 2019). Consumer decision-making can be defined as the right for consumers constantly make decisions regarding the choice, purchase, and use of products and services (James et al., 2015).

Consumers are often faced with the alternative, which is constantly changing due to the fast-developing technologies and competitive pressures, such as the new media platform and portable equipment. These decisions are of great importance not only for the consumer themselves, but also for the marketer (media organization) and policymaker (government) (James et al., 2015). The significance of the decision making of customer or audience is reflecting on how marketers can enhance marketing activities to attract consumers more effectively (Alina, 2017). Because the audience or viewer is one of the key elements of media 
studies (James, 1998). Similarly, "The media needs an audience to achieve its goals, and to find that audience, they must compete with each other in the market, they focus (James, 2015)."Previously, consumer decision-making indicated that according to the assumptions and knowledge of consumer behavior (Hawkins, 2007) to decide on the market. It means based on the prediction of rating and analysis of viewing behavior.

While large previous research on viewers paid attention to audiences' selection of program content instead of on measures of viewing patterns (Patric \& Andrew,2014). The choice is made to achieve goals (Bettmen, 1979). Consumers are fond of their products or services. Therefore, the exploration of purchasing behavior reveals how consumers think, perceive, talk, and choose among the existing choices (e.g., brands, goods, and retailers), also how the consumer's environment (e.g., culture, family, media) affects him or her (Alina, 2017). Recent anecdotal studies showing that viewing decisions made by various groups (characteristics, age, class, geographic location) in the now more competitive environment have become increasingly significant (Manouche \& Martin, 2016) and media consumption was indicated that not only related to a person's self-image, but also related to the "social self" projected by him or her.

Television as a medium is rarely considered in the light of how we as viewers actually use it (Patric \& Andrew, 2014). Deeper into the usage of TV as a lifestyle, clarifying the decision made to watch television as largely negative while the choice of what content to watch is more positive, in other words, when watching TV, habits may play a greater role in decisionmaking than when watching a program (Aviva \& August, 1997). As an audience flow model for measuring television viewing choice illustrates the necessity to draw behavior at the individual level when modeling the choice of television viewing. Viewing choice is described either at the aggregate level or the individual level that many past literatures explicitly display that individual differences happen in viewing choice (Roland \& Mark, 1984). For example, there was a generally expected pattern of viewing behavior, the number of males is higher than those of females watching sports program at all education levels. The factor analysis method that defines the program category is controversial. (Roland \& Mark,1984). Thus this study hypothesize that there is a significant differences on the discrete choice of a program to watch in fulfilling five needs in uses gratification (cognitive, personal, emotion, social and self-expression) between Malay and Non-Malay.

Consumption is more than just satisfying physical needs. The stuff we consume can be utilized in our life existing as social currency, identity statement, self-branding tool, value signal, or emotion regulation tool (Roland \& Mark, 1984). As Belk, Fournier, Escalas and Bettman mentioned that consumers use ownership and brand to build identity. Thus, we select what we consume to identify ourselves (Escalas\& Bettman, 2005) and due to specific products are linked, or enable specific social roles (Kleine,1993). As proved by Luomala (2000), people utilize specific behavior deliberately to change their bad mood, and usually, those activities chosen to alter moods are also working well.

From the discussion based on the past literature, two hypotheses were constructed which are:

H 1: $\quad$ There is the significant differences between Malay and Non-Malay in preferred programs on portal TV to satisfy their needs' gratification. 
$\mathrm{H}$ 2: $\quad$ There is a strong influence of preferred programs on portal TV in satisfying their needs on media consumption gratification to Malay compared to Non-Malay.

\section{Methods}

Data was collected through a self-administered survey of university students and working adults in Bandar Baru Bangi, Selangor for one main reason, the location is highly populated with working adults that come from many ethnicities. A multistage sampling method was used to collect the data from 175 respondents (93 Malay and 82 Non-Malay). Since Partial Least Squares-Multi Group Analysis (PLS - MGA) was used to analyze data for this study, a normal distribution of samples is not a crucial factor since for the prediction model enough sampling number to achieve statistical power of the model is more important (Cachón Rodríguez et al., 2019; Cheah et al., 2020). The G*Power 3.1.9.2 software was used to obtain the minimum sample size necessary to have sufficient test power recommended by authors as Hair et al. (2018). The results require a minimum sample size of 55 cases for a power test of $80 \%$, minimum requirement where the number of respondents for each group is well surpassed the minimum value (Cohen, 1988). The effect of the ethnicity was analysed by using bootstrapping method with 1000 iterations in order to produce a good result (Cheah et al., 2020; Ghazali et al., 2019; Hair et al., 2019).

\section{Control variables}

The categorical type of demographic data for "Ethnic" in this study (Malay/ Bumiputra, Chinese, Indian and others) was transposed into discrete choice modeling (DCM). DCM used Boolean block algorhytm in determining the factor loading of the observed variables (Hair et al., 2019).

\section{Results}

The results of the PLS-MGA as shown in Table 1 indicates the group differences for respondents between Malay and Non-Malay in terms of their differences and influence on the relationship between the exogenous variables and the endogenous variable. 
Table 1

MICOM Procedure Results (Malay/ Bumiputra vs Non-Bumiputra) $(n=1000)$

\begin{tabular}{|c|c|c|c|c|c|c|c|c|c|c|}
\hline & \multirow{2}{*}{\multicolumn{2}{|c|}{$\begin{array}{c}\text { Invarianc } \\
\text { e of } \\
\text { Composit } \\
\text { e }\end{array}$}} & \multirow{3}{*}{$\begin{array}{l}\text { Partial } \\
\text { Invarian } \\
\text { ce }\end{array}$} & \multirow{2}{*}{\multicolumn{3}{|c|}{$\begin{array}{c}\text { EQUALITY OF MEASURES } \\
\text { CONFIDENCE } \\
\text { INTERVAL } \\
95 \% \mathrm{Cl}\end{array}$}} & \multicolumn{4}{|c|}{ EQUALITY OF VARIANCES } \\
\hline & & & & & & & 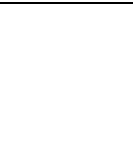 & $\begin{array}{r}\text { CON } \\
\text { E IN } \\
95\end{array}$ & $\begin{array}{l}\text { IDENC } \\
\text { ERVAL } \\
\% \mathrm{Cl}\end{array}$ & Total \\
\hline & $\begin{array}{c}C= \\
1\end{array}$ & $\begin{array}{c}5 \% \\
\mathrm{C}_{\mathrm{u}} \\
\end{array}$ & & $\begin{array}{c}\text { Differe } \\
\text { nces }\end{array}$ & $\begin{array}{l}2.5 \\
0 \% \\
\end{array}$ & $\begin{array}{c}97.50 \\
\% \\
\end{array}$ & $\begin{array}{c}\text { Differe } \\
\text { nces }\end{array}$ & $\begin{array}{l}2.5 \\
0 \% \\
\end{array}$ & $\begin{array}{c}97.50 \\
\% \\
\end{array}$ & $\begin{array}{c}\text { Invari } \\
\text { ance }\end{array}$ \\
\hline $\begin{array}{l}\text { Cognitive } \\
\text { Need }\end{array}$ & $\begin{array}{l}0.7 \\
89\end{array}$ & $\begin{array}{l}0.9 \\
87\end{array}$ & No & 0.672 & $\begin{array}{c}- \\
0.1 \\
84\end{array}$ & 0.188 & -0.833 & $\begin{array}{c}- \\
0.2 \\
01\end{array}$ & 0.234 & No \\
\hline $\begin{array}{l}\text { Emotion } \\
\text { Need }\end{array}$ & 1 & $\begin{array}{c}0.9 \\
94\end{array}$ & Yes & 0.732 & $\begin{array}{c}- \\
0.1 \\
93\end{array}$ & 0.186 & -0.961 & $\begin{array}{c}- \\
0.2 \\
01\end{array}$ & 0.232 & No \\
\hline $\begin{array}{l}\text { Personal } \\
\text { Need }\end{array}$ & $\begin{array}{l}0.9 \\
99\end{array}$ & $\begin{array}{l}0.9 \\
96\end{array}$ & Yes & 0.616 & $\begin{array}{c}- \\
0.1 \\
76\end{array}$ & 0.191 & -0.917 & $\begin{array}{c}- \\
0.2 \\
27\end{array}$ & 0.256 & No \\
\hline $\begin{array}{l}\text { Self- } \\
\text { Expression } \\
\text { Need }\end{array}$ & 1 & $\begin{array}{c}0.9 \\
95\end{array}$ & Yes & 0.407 & $\begin{array}{c}- \\
0.1 \\
93\end{array}$ & 0.183 & -0.52 & $\begin{array}{c}- \\
0.1 \\
73\end{array}$ & 0.186 & No \\
\hline Social Need & $\begin{array}{l}0.7 \\
67\end{array}$ & $\begin{array}{c}0.9 \\
68\end{array}$ & No & 0.65 & $\begin{array}{c}- \\
0.2 \\
07\end{array}$ & 0.189 & -0.799 & $\begin{array}{c}- \\
0.2 \\
03\end{array}$ & 0.223 & No \\
\hline $\begin{array}{l}\text { Types of } \\
\text { programs } \\
\text { frequently } \\
\text { watched }\end{array}$ & $\begin{array}{l}0.9 \\
91\end{array}$ & $\begin{array}{l}0.9 \\
86\end{array}$ & Yes & 0.031 & $\begin{array}{c}- \\
0.1 \\
89\end{array}$ & 0.187 & -0.218 & $\begin{array}{c}- \\
0.1 \\
68\end{array}$ & 0.191 & No \\
\hline
\end{tabular}

Table 2

PLS-MGA for Respondents Between Malay/ Bumiputra vs Non-Bumiputra

\begin{tabular}{|c|c|c|c|c|c|c|c|c|}
\hline & \multirow{5}{*}{$\begin{array}{c}\text { Path } \\
\text { Coeffic } \\
\text { ients } \\
\text { (Bumi } \\
\text { putra) }\end{array}$} & \multirow{5}{*}{$\begin{array}{l}\text { Path } \\
\text { Coeffic } \\
\text { ients } \\
\text { (Non- } \\
\text { Bumip } \\
\text { utra) }\end{array}$} & \multirow{5}{*}{$\begin{array}{c}\text { Path } \\
\text { Coeffic } \\
\text { ients } \\
\text { Differe } \\
\text { nce }\end{array}$} & \multicolumn{4}{|c|}{$p$-Value } & \multirow[b]{5}{*}{$\begin{array}{c}\text { Accept } \\
\text { ance }\end{array}$} \\
\hline & & & & & \multirow[b]{4}{*}{$\begin{array}{l}97 . \\
5 \% \\
\end{array}$} & Differe & two & \\
\hline & & & & \multirow[b]{3}{*}{$2.5 \%$} & & nce & tails & \\
\hline & & & & & & $\begin{array}{l}\text { Permut } \\
\text { ation }\end{array}$ & $\begin{array}{c}\mathrm{p}- \\
\text { Value }\end{array}$ & \\
\hline & & & & & & $\begin{array}{c}p- \\
\text { Values }\end{array}$ & MGA & \\
\hline $\begin{array}{l}\text { Types of programs } \\
\text { frequently watched } \\
\text { in Portal TV -> } \\
\text { Cognitive Need }\end{array}$ & -0.186 & -0.596 & 0.41 & $\begin{array}{c}- \\
0.13 \\
4\end{array}$ & $\begin{array}{l}0.1 \\
28\end{array}$ & & 0 & Yes \\
\hline $\begin{array}{l}\text { Types of programs } \\
\text { frequently watched } \\
\text { in Portal TV -> } \\
\text { Emotion Need }\end{array}$ & -0.185 & -0.554 & 0.369 & $\begin{array}{c}0.13 \\
7\end{array}$ & $\begin{array}{c}0.1 \\
3\end{array}$ & & & Yes \\
\hline
\end{tabular}


Types of programs

frequently watched

in Portal TV ->

$\begin{array}{lllllll}-0.118 & -0.487 & 0.369 & -0.14 & 0.1 & 0 & \text { Yes }\end{array}$

Personal Need

Types of programs

frequently watched

in Portal TV -> Self-

$\begin{array}{lllllll}-0.189 & -0.453 & 0.264 & 0.13 & 0.1 & 0.001 & \text { Yes }\end{array}$

Expression Need

Types of programs

frequently watched

in Portal TV $->$ Social

$-0.216-0.506$

0.29

0.13

0.1
21

$0.019 \quad 0.005$

Yes

Need

Hypothesis 1 stated that there is a significant difference between Malay workers and Non-Malay workers in terms of the relationship preferred programs on portal TV in satisfying their needs on gratification. This hypothesis was supported as shown by the significant result $(\beta=.1,0.999,1 p>$. 95) (See Table 1). Hypothesis 2 stated that there is a strong influence of preferred programs on portal TV in satisfying their needs on media consumption gratification to Malay compared to Non-Malay. This hypothesis was supported as evidenced by the significant result $(\beta=0.41,0.369,0.369,0.264,0.29, p<.05)$ which indicates that Malay workers have a strong influence on the preferred programs on portal TV in satisfying their needs on media consumption gratification (See Table 2).

\section{Conclusion}

This study examined the differences and the influence between Malay and Non-Malay worker in the frequent watched programs on portal tv and the satisfaction of gratification needs. It has a theoretical implication through extending the uses and gratification theory on Malaysian audience. Thus, this study contributes to the novelty for uses and gratifications theory by adding that the differences in ethnicity does influence the working adults on their media comsumption to gratify the needs. Furthermore, the study lends empirical support to the relationship between variables of the theory and the usage of portal TV by working adults. In the context of TV station or organisation, audience satisfaction is very significant in an organization. It will determine the organization efficiency, effectiveness and productivity. An organization with the highly satisfied audience are more focused, creative at work, care about the organization, put greater effort to meet its objectives, feel motivated and will do the best for the organization.

Practically, this research is significant with the current development context. In the advancement of digital world today, organizations is competing each other in order to sustain their position and also in maintaining their corporate reputation. It is important for the organization to ensure that their productivity is well observed. In order to achieve this, it involves audience satisfaction. Nevertheless, this study is limited in the nature of its design as the cross sectional survey approach which was used did not allow for causal inferences to be made from the population over a long period of time. Thus, it is recommended that a longitudinal design which could measure the media consumption patterns among working adults from different ethnic over a long period of time needs to be carried out for future research. 


\section{Reference}

Abu-Alhaija, A. S., Raja Yusof, R. N., Hashim, H., \& Jaharuddin, N. (2019). The influence of religious orientation on viewers' loyalty towards satellite TV channels: The case of Muslim viewers. Journal of Islamic Marketing, 10(4), 1196-1218.

Alpert, M. I., \& Rust, R. T. (1984). An Audience Flow Model of Television Viewing Choice. In Marketing Science, 3(2), 113-124.

Andersen, K., Skovsgaard, M., \& Pedersen, R. T. (2019). The X Factor of opportunity structures: How grab and wrap effects of entertainment create inadvertent news audience in a high-choice media environment. European Journal of Communication, 34(5), 535-551.

Andrade, L. H. de, Antunes, J. J. M., \& Wanke, P. (2020). Performance of TV programs: a robust MCDM approach. Benchmarking, 27(3), 1188-1209.

Audiences, W. T. (2000). Watching Television Audiences: Cultural Theories and Methods. Watching Television Audiences : Cultural Theories and Methods, London: Arnold

Badarudin, N. B. (1997). Programming Content in Malaysian Television. Media Asia, 24(3), 146-149.

Bagdasarov, Z., Greene, K., Banerjee, S. C., Krcmar, M., Yanovitzky, I., \& Ruginyte, D. (2010). I am what i watch: Voyeurism, sensation seeking, and television viewing patterns. Journal of Broadcasting and Electronic Media, 54(2), 299-315.

Bakewell, C., \& Mitchell, V. W. (2003). Generation Y female consumer decision-making styles. International Journal of Retail \& Distribution Management, 31(2), 95-106.

Balcı, Ş., \& Ayhan, B. (2015). Patterns of television viewing behavior in Kyrgyzstan: A perspective of uses and gratifications. Bilig, 75(75), 275-312.

Barwise, P., \& Ehrenberg, A. (2014). Television and its Audience. Television and Its Audience.

Bayo-Moriones, A., Etayo, C., \& Sánchez-Tabernero, A. (2015). Political orientation and perceived quality of television channels. Journal of Service Theory and Practice, 25(6), 813-835.

Bielby, W. T., \& Bielby, D. D. (1994). "All Hits Are Flukes": Institutionalized Decision Making and the Rhetoric of Network Prime-Time Program Development. American Journal of Sociology, 99(5), 1287-1313.

Bondad-Brown, B. A., Rice, R. E., \& Pearce, K. E. (2012). Influences on TV Viewing and Online User-shared Video Use: Demographics, Generations, Contextual Age, Media Use, Motivations, and Audience Activity. Journal of Broadcasting and Electronic Media, 56(4), 471-493.

Bourdon, J., \& Ribke, N. (2016). Ratings, the state and globalization: the politics of television audience measurement in Israel. Media, Culture and Society, 38(2), 159-174.

Brooks, D. E., \& Hébert, L. P. (2006). Gender, race, and media representation. The SAGE Handbook of Gender and Communication, Sage Publications, Inc.

Buckingham, D. (2007). A Special Audience? Children and Television. A Companion to Television, 468-486.

Bunker, D., \& Bryson, J. (2016). Gender and the media: Investigating audience opinions on TV, radio and the Internet. International Journal of Market Research, 58(3), 355-380.

Condit, C. M. (1989). The rhetorical limits of polysemy. Critical Studies in Mass Communication, 6(2), 103-122.

Cooper, R. (2018). The Marketplace of Attention: How Audiences Take Shape in the Digital Age. Journal of Broadcasting \& Electronic Media, 62(1), 183-185. 
Daalmans, S., Kleemans, M., \& Sadza, A. (2017). Gender Representation on Gender-Targeted Television Channels: A Comparison of Female- and Male-Targeted TV Channels in the Netherlands. Sex Roles, 77(5-6), 366-378.

Debate, F., \& Decision, V. (2009). Media Effects from Debate Effects : Presentation Mode of Televised, J\&MC Quarterly, 86(2), 383-400,

Desa, K., \& Lawang, B. (2009). Korean Wave and Malaysian Young Adults: Attitudes, Intention and Behaviour. Gender \& Behaviour, 17(1-2), 1-19.

Evans, W. P., Fitzgerald, C., Weigel, D., \& Chvilivek, S. (1999).Televison Structures and Adolescent Viewing Pattern: A Sweidish -American Comparison. European Jounal of Communication. 6(1991), 417-440.

Falero, S. M. (2016). Digital participatory culture and the TV audience. DOI 10.1057/978-1137-50000-7

February, B., Far, T., Economic, E., Raman, G., \& Lent, J. A. (1976). John A . Lent True (?) confessions - TV in Malaysia. 7(2), 9-18.

Ferguson, D. A., \& Perse, E. M. (2004). Audience Satisfaction Among Tivo and Replaytv Users. Journal of Interactive Advertising, 4(2), 1-8.

Fikkers, K. M., \& Piotrowski, J. T. (2020). Content and person effects in media research: Studying differences in cognitive, emotional, and arousal responses to media content. Media Psychology, 23(4), 493-520.

Greene, H., \& Yao, D. A. (2016). Navigating natural monopolies: Market strategy and nonmarket challenges in radio and television audience measurement markets. Advances in Strategic Management, 34, 367-411.

Halford, J. (1996). Sensation seeking, television viewing motives, and home television viewing patterns Notes and Shorter Communications. Science, 21(6), 1081-1084.

HEETER, C. (1985). Program Selection With Abundance of Choice. Human Communication Research, 12(1), 126-152.

Hill, A. (2007). Reality TV: Performance, Authenticity, and Television Audiences. A Companion to Television, 449-467.

Islam, M. M. (2018). Television Viewing Patterns and Program Choices of Rural and Urban Audiences. Society \& Change, XII(2), 7-22.

Ivala, E. (2007). Television audience research revisited: Early television audience research and the more recent developments in television audience research. Communicatio, 33(1), 26-41.

Jardine, B., Romaniuk, J., Dawes, J. G., \& Beal, V. (2016). Retaining the primetime television audience. European Journal of Marketing, 50(7-8), 1290-1307.

Jennes, I., \& Van den Broeck, W. (2014). Digital TV innovations: Industry and user perspective. Info, 16(6), 48-59.

Journal, S., Winter, N., Taylor, P., Tavakoli, M., \& Cave, M. (2016). Taylor \& Francis, Ltd. 25(4), 71-86.

Karthigesu, K. (1990). Television in Malaysia: An Examination of Policy Formulation. Media Asia, 17(3), 131-136.

Kim, J., Merrill, K., \& Yang, H. (2019). Why we make the choices we do: Social TV viewing experiences and the mediating role of social presence. Telematics and Informatics, 45(September), 101281.

Kim, W. L. (2001). Media and democracy in Malaysia. Javnost, 8(2), 67-88.

Abd Halim, N., \& Rosidi, I. (2012). Television, Youth Identity and Value Socialisation: A Study Among Students in Pekanbaru, Riau, Indonesia. Media Asia, 39(1), 46-60. 
Rodríguez, C. G., Prado Román, C., \& Zúñiga-Vicente, J. Á. (2019). The relationship between identification and loyalty in a public university: Are there differences between (the perceptions) professors and graduates? European Research on Management and Business Economics, 25(3), 122-128.

Cheah, J. H., Thurasamy, R., Memon, M. A., Chuah, F., \& Ting, H. (2020). Multigroup analysis using smartpls: Step-by-step guidelines for business research. Asian Journal of Business Research, 10(3), I-XIX.

Ghazali, E. M., Mutum, D. S., \& Woon, M. Y. (2019). Multiple sequential mediation in an extended uses and gratifications model of augmented reality game Pokémon Go. Internet Research, 29(3), 504-528.

Hair, J. F., Ringle, C. M., Gudergan, S. P., Fischer, A., Nitzl, C., \& Menictas, C. (2019). Partial least squares structural equation modeling-based discrete choice modeling: an illustration in modeling retailer choice. Business Research, 12(1), 115-142.

Kurek, A., Jose, P. E., \& Stuart, J. (2017). Discovering unique profiles of adolescent information and communication technology (ICT) use: Are ICT use preferences associated with identity and behaviour development? Cyberpsychology, 11(4), Article 3.

LaRose, R., \& Atkin, D. (1988). Satisfaction, Demographic, and Media Environment Predictors of Cable Subscription. Journal of Broadcasting \& Electronic Media, 32(4), 403-413.

Leung, L., \& Chen, C. (2017). Extending the theory of planned behavior: A study of lifestyles, contextual factors, mobile viewing habits, TV content interest, and intention to adopt mobile TV. Telematics and Informatics, 34(8), 1638-1649.

Lim, C. M., \& Kim, Y. K. (2017). Older consumers' TV shopping: emotions and satisfaction. International Journal of Retail and Distribution Management, 45(3), 292-307.

Lin, C. A. (2018). An Inspiring Year in Audience, Media, and Digital Technology Research. Journal of Broadcasting and Electronic Media, 62(4), 547-553.

LIN, C. A. (1993). Modeling the Gratification-Seeking Process of Television Viewing. Human Communication Research, 20(2), 224-244.

Luce, M. F. (2015). The Wiley Blackwell Handbook of Judgment and Decision Making, UK; John Wiley \&Son, Ltd.

Madahi, A., Sukati, I., Mazhari, M. Y., \& Rashid, W. N. (2012). Consumer decision making styles amongst young generation in Malaysia. European Journal of Social Sciences, 30(2), 263275.

Maio, G. R., \& Esses, V. M. (2001). The need for affect: Individual differences in the motivation to approach or avoid emotions. Journal of Personality, 69(4), 583-614.

Maity, M., \& Dass, M. (2014). Consumer decision-making across modern and traditional channels: E-commerce, m-commerce, in-store. Decision Support Systems, 61(1), 34-46.

Maxwell, R. (2000). Picturing the Audience. Television \& New Media, 1(2), 135-157.

McDonald, D. G. (1990). Media Orientation and Television News Viewing. Journalism Quarterly, 67(1), 11-20.

McDowell, W., \& Sutherland, J. (2000). Choice versus chance: Using brand equity theory to explore TV audience lead-in effects, a case study. Journal of Media Economics, 13(4), 233-247.

Medina, M., Herrero, M., Urgellés, A., \& Herrero, M. (2017). The Battle for Audiences. Current and Emerging Issues in the Audiovisual Industry, 65-76.

Meyersohn, R. B. (1957). What we know about audiences*. Journal of Broadcasting, 1(3), 220-231. 
Mohamed, S. (2020). New Media, Cultural Imperialism and the Malay Muslim Society in Malaysia. Journal of Islamic, Social, Economics and Development (JISED), 5 (29),19-33.

Molteni, L., \& Ponce De Leon, J. (2016). Forecasting with twitter data: An application to USA TV series audience. International Journal of Design and Nature and Ecodynamics, 11(3), 220-229.

Morley, D. (2003). Television, audiences and cultural studies (1st edition ), London ; New York : Routledge Routledge.

Nain, Z. (1996). Rhetoric and realities Malaysian television policy in an era of globalization. Asian Journal of Communication, 6(1), 43-64.

Norwood, B. (2011). Happiness: A Revolution in Economics, London: The MIT Press.

Onah, J. O., \& Anyanwu, A. V. (1988). Viewer preference for TV stations and programmes: a pilot study. Africa Media Review, 2(3), 1-18.

Panova, E., Raikov, A., \& Smirnova, O. (2015). Cognitive Television Viewer Rating. In Procedia Computer Science , 66. 328-335.

Peruško, Z., Vozab, D., \& Čuvalo, A. (2015). Digital mediascapes, institutional frameworks, and audience practices across Europe. International Journal of Communication, 9(1), 342364.

Ponnan, R., \& Ali, M. N. S. (2015). SOCIAL MEDIA ISSUES EMBEDDED IN BROADCASTING: MALAYSIAN EXPERIENCE Ramachandran Ponnan \& Mohd. Nor Shahizan Ali. Journal of Social Sciences and Humanities, 10(1), 29-43.

Publications, S. (2010). Television' s Visual Impact on Decision- making in the USA , 1968 : The Tet Offensive and Chicago 's Democratic National Convention. Journal Of Contemporary History, 33(3), 419-449.

Ramasubramanian, S. (2010). Television viewing, racial attitudes, and policy preferences: Exploring the role of social identity and intergroup emotions in influencing support for affirmative action. Communication Monographs, 77(1), 102-120.

Rodríguez, C., Pérez, L., Puente, V., \& Rodríguez, P. (2012). The determinants of television audience for professional cycling: The case of spain. Journal of Sports Economics, 16(1), 26-58.

Rosenstein, A. W., \& Grant, A. E. (1997). Reconceptualizing the role of habit: A new model of television audience activity. Journal of Broadcasting \& Electronic Media, 41(3), 324344.

Ross, Karen, Nightingale, \& Virginia. (2003). Media And Audiences: New Perspectives.

Rubin, A. M. (1977). Television usage, attitudes and viewing behaviors of children and adolescents. Journal of Broadcasting, 21(3), 355-369.

Rubin, A. M. (1983). Television uses and gratifications: The interactions of viewing patterns and motivations. Journal of Broadcasting, 27(1), 37-51.

Saarni, C., Campos, J. J., Camras, L. A., \& Witherington, D. (1993). Key Concepts in Communication and Culture Studies, (2nd ed.), London.: Taylor Francis Group.

Schooler, D., \& Trinh, S. (2011). Longitudinal associations between television viewing patterns and adolescent body satisfaction. Body Image, 8(1), 34-42.

Schreiber, E. S. (1979). The effects of sex and age on the perceptions of TV characters: An inter-age comparison. Journal of Broadcasting, 23(1), 81-93.

Segijn, C. M., Araujo, T., Voorveld, H. A. M., \& Smit, E. G. (2020). Related Multiscreening as a Strategy to Retain Audiences and Increase Persuasion During a Commercial Break. Journal of Broadcasting and Electronic Media, 64(1), 41-61. 
Selva, D. (2016). Social Television: Audience and Political Engagement. Television and New Media, 17(2), 159-173.

Shachar, R., \& Emerson, J. W. (2000). Cast demographics, unobserved segments, and heterogeneous switching costs in a television viewing choice model. Journal of Marketing Research, 37(2), 173-186.

Shim, S. (1996). Adolescent consumer decision-making styles: The consumer socialization perspective. Psychology and Marketing, 13(6), 547-569.

Shim, S., \& Koh, A. (1997). Profiling adolescent consumer decision-making styles: Effects of socialization agents and social-structural variables. Clothing and Textiles Research Journal, 15(1), 50-59.

Simcock, P., Sudbury, L., \& Wright, G. (2006). Age, Perceived Risk and Satisfaction in Consumer Decision Making: A Review and Extension. Journal of Marketing Management, 22(3-4), 355-377.

Smith, D. C. (1961). The selectors of television programs. Journal of Broadcasting, 6(1), 3544.

Solgaard, H. S. (1984). A model of audience choice of local TV news program. International Journal of Research in Marketing, 1(2), 141-151.

Stankevich, A. (2017). Explaining the Consumer Decision-Making Process: Critical Literature Review. Journal of International Business Research and Marketing, 2(6), 7-14.

Sugiyama, T., Healy, G. N., Dunstan, D. W., Salmon, J., \& Owen, N. (2008). Is television viewing time a marker of a broader pattern of sedentary behavior? Annals of Behavioral Medicine, 35(2), 245-250.

Sun, T. (2009). Parental mediation of children's TV viewing in China: An urban-rural comparison. Young Consumers, 10(3), 188-198.

Sussman, S., \& Moran, M. B. (2013). Hidden addiction: Television. Journal of Behavioral Addictions, 2(3), 125-132.

Tavakoli, M., \& Cave, M. (1996). Modelling television viewing patterns. Journal of Advertising, 25(4), 71-86.

Tefertiller, A., \& Sheehan, K. (2019). TV in the Streaming Age: Motivations, Behaviors, and Satisfaction of Post-Network Television. Journal of Broadcasting and Electronic Media, 63(4), 595-616.

Ugalde, L., Martínez-de-Morentin, J. I., \& Medrano, M. C. (2017). Adolescents' Tv viewing patterns in the digital era: A cross-cultural study. Comunicar, 25(50), 67-75.

Vorderer, P. (1993). Audience involvement and program loyalty. Poetics, 22(1-2), 89-98.

Walsh, G., Mitchell, V. W., \& Hennig-Thurau, T. (2001). German consumer decision-making styles. Journal of Consumer Affairs, 35(1), 73-95.

Webster, J. G. (1985). Program Audience Duplication: A Study of Television Inheritance Effects. Journal of Broadcasting \& Electronic Media, 29(2), 121-133.

Willman-livarinen, H. (2017). The future of consumer decision making. European Journal of Futures Research, 5(14), 1-12.

Woodford, D., Goldsmith, B., \& Bruns, A. (2015). Social Media Audience Metrics as a New Form of TV Audience Measurement. Produsing Theory in a Digital World 2.0: The Intersection of Audiences and Production in Contemporary Theory, 2, 141-158.

Yuan, E., \& Ksiazek, T. (2015). A Network Analytic Approach to Audience Behavior and Market Structure: The Case of China and the United States. Mass Communication and Society, 18(1), 58-78. 
INTERNATIONAL JOURNAL OF ACADEMIC RESEARCH IN BUSINESS AND SOCIAL SCIENCES

Vol. 11, No. 8, 2021, E-ISSN: 2222-6990 @ 2021 HRMARS

Zailani, S. (2015). Designing to engage a television audience: how are different media used in TV ident creation? The Eletronic Library, 34(1), 1-5. 